\title{
Physical and bacterial controls on inorganic nutrients and dissolved organic carbon during a sea ice growth and decay experiment
}

\author{
J. Zhou ${ }^{\text {a,b,*, }}$, B. Delille ${ }^{\text {b }}$, H. Kaartokallio ${ }^{\text {c }}$, G. Kattner ${ }^{\text {d }}$, H. Kuosa ${ }^{\text {c }}$, J.-L. Tison ${ }^{\text {a }}$, R. Autio ${ }^{\text {, }}$, G.S. Dieckmann ${ }^{\text {d }}$, \\ K.-U. Evers ${ }^{\text {e }}$, L. Jørgensen ${ }^{\text {f,g }}$, H. Kennedy ${ }^{\text {h }}$, M. Kotovitch ${ }^{\text {a,b }}$, A.-M. Luhtanen ${ }^{\text {c,i }}$, C.A. Stedmon ${ }^{g}$, D.N. Thomas ${ }^{\text {c,h }}$ \\ a Laboratoire de glaciologie, DSTE, Université Libre de Bruxelles, Belgium \\ b Unité d'océanographie chimique, MARE, Université de Liège, Belgium \\ ${ }^{c}$ Marine Research Centre, Finnish Environment Institute (SYKE), Helsinki, Finland \\ d Alfred Wegener Institute Helmholtz Center for Polar and Marine Research, Bremerhaven, Germany \\ e Arctic Technology Department, HSVA, Germany \\ ${ }^{\mathrm{f}}$ Department of Biology, Marine Biological Section, University of Copenhagen, Denmark \\ g National Institute for Aquatic Resources, Technical University of Denmark, Denmark \\ h School of Ocean Sciences, Bangor University, Menai Bridge, United Kingdom \\ i Department of Biosciences, University of Helsinki, Finland
}

\section{A R T I C L E I N F O}

\section{Article history:}

Received 12 May 2014

Received in revised form 19 September 2014

Accepted 26 September 2014

Available online 5 October 2014

\section{Keywords:}

Sea ice

Brine dynamics

Bacterial activity

Inorganic nutrients

Dissolved organic carbon

\begin{abstract}
A B S T R A C T
We investigated how physical incorporation, brine dynamics and bacterial activity regulate the distribution of inorganic nutrients and dissolved organic carbon (DOC) in artificial sea ice during a 19-day experiment that included periods of both ice growth and decay. The experiment was performed using two series of mesocosms: the first consisted of seawater and the second consisted of seawater enriched with humic-rich river water. We grew ice by freezing the water at an air temperature of $-14{ }^{\circ} \mathrm{C}$ for 14 days after which ice decay was induced by increasing the air temperature to $-1{ }^{\circ} \mathrm{C}$. Using the ice temperatures and bulk ice salinities, we derived the brine volume fractions, brine salinities and Rayleigh numbers. The temporal evolution of these physical parameters indicates that there was two main stages in the brine dynamics: bottom convection during ice growth, and brine stratification during ice decay. The major findings are: (1) the incorporation of dissolved compounds (nitrate, nitrite, ammonium, phosphate, silicate, and DOC) into the sea ice was not conservative (relative to salinity) during ice growth. Brine convection clearly influenced the incorporation of the dissolved compounds, since the non-conservative behavior of the dissolved compounds was particularly pronounced in the absence of brine convection. (2) Bacterial activity further regulated nutrient availability in the ice: ammonium and nitrite accumulated as a result of remineralization processes, although bacterial production was too low to induce major changes in DOC concentrations. (3) Different forms of DOC have different properties and hence incorporation efficiencies. In particular, the terrestrially-derived DOC from the river water was less efficiently incorporated into sea ice than the DOC in the seawater. Therefore the main factors regulating the distribution of the dissolved compounds within sea ice are clearly a complex interaction of brine dynamics, biological activity and in the case of dissolved organic matter, the physico-chemical properties of the dissolved constituents themselves.
\end{abstract}

(C) 2014 Elsevier B.V. All rights reserved.

\section{Introduction}

Sea ice is formed from the freezing of seawater, and therefore the dissolved inorganic and organic nutrient concentrations in sea ice depend on those of the parent water (Petrich and Eicken, 2010; Weeks, 2010). Most of these compounds are concentrated in the brine inclusions, as they are not incorporated within the matrix of pure ice crystals (Weeks, 2010).

* Corresponding author at: Laboratoire de glaciologie, DSTE, Université Libre de Bruxelles, Belgium.

E-mail address: jiayzhou@ulb.ac.be (J. Zhou).
The two principal regions of sea ice production, the Arctic and Southern Oceans, differ widely in the concentrations of nutrients and dissolved organic matter (DOM) present in the surface waters from which sea ice is formed. The waters of the Arctic Ocean have comparatively lower nutrient concentrations (e.g., nitrate and phosphate), except the Pacific water inflow, but higher input of riverine particulates and DOM, as well as silicate (Dittmar et al., 2001; Wheeler et al., 1997). In contrast, the Southern Ocean generally has high inorganic nutrient concentrations (Gleitz et al., 1994), whereas DOM is of oceanic origin and at comparatively low concentrations (Hansell et al., 2009). A consequence of this fundamental difference is that Arctic sea ice can be expected to have a higher DOM content 
than ice produced in the Southern Ocean (Stedmon et al., 2007, 2011), and as such may promote greater bacterial production, leading to higher $\mathrm{pCO}_{2}$ concentrations in the brines (Geilfus et al., 2012). In turn, this could result in the air-ice $\mathrm{CO}_{2}$ exchange in the Arctic and Antarctic being fundamentally different, although this hypothesis is yet to be verified.

In addition to bacterial production, other mechanisms may regulate differences in the dynamics of dissolved constituents (nutrients and DOM) in sea ice. Previous studies have indicated selective incorporation of DOM during sea ice formation (Aslam et al., 2012; Giannelli et al., 2001; Müller et al., 2013), raising the question as to whether or not there is a segregation among dissolved compounds during the incorporation phase, and in particular, whether the incorporation is comparable between Arctic and Antarctic sea ice because of the different compositions of DOM in the parent waters. Various physical mechanisms induce changes in the nutrient pools in ice after the initial incorporation. Among these, brine convection is the most important during ice growth (Notz and Worster, 2009; Vancoppenolle et al., 2010). Flushing (Eicken et al., 2004) and flooding (Fritsen et al., 2013, 2001) may also be significant, but their impact remains difficult to assess (e.g., Pringle and Ingham, 2009).

The aim of the present study was to better understand the differences in sea ice biogeochemistry and bacterial activity, related to additional allochthonous riverine DOC during a whole cycle of sea ice formation, consolidation and subsequent decay. In our mesocosm experiment, we reproduced ice growth and ice decay on two series of mesocosms: One consisting of North Sea seawater and the other consisting of North Sea seawater amended with 10\% natural DOM-rich river water. The latter was designed to simulate the dissolved organic matter conditions that occur in Arctic shelf waters where much ice formation occurs. We hypothesized that the dissolved compounds of the parent waters would be predominantly incorporated conservatively into the ice (relative to salinity), and would then deviate from the conservative behavior due to bacterial activity, given that there was no autotrophic component in the experiment. We also expected that a deviation from the conservative behavior would be higher in the river-water amended mesocosms because the higher organic matter content would stimulate bacterial activity, if the riverine DOM is bioavailable.

\section{Material and methods}

\subsection{Experimental setting and sampling routine}

The 19-day experiment took place in the Hamburg Ship Model Basin (www.hsva.de). We used 21 polyethylene experimental mesocosms with a volume of $1.2 \mathrm{~m}^{3}$ each. Eleven of the mesocosms were filled with $1000 \mathrm{~L}$ of seawater from the North Sea (referred hereafter as SW), and the remaining 10 were filled with $900 \mathrm{~L}$ of seawater from the North Sea and $100 \mathrm{~L}$ of river water (referred hereafter as SWR). The North Sea water was collected on 24 May $2012\left(54^{\circ} 7^{\prime} \mathrm{N}\right.$ $7^{\circ} 54^{\prime} \mathrm{E}$ near Helgoland) and transported to Hamburg where the mesocosms were filled within $24 \mathrm{~h}$ of collection. The river water was collected during spring freshet in mid-May 2012 from River Kiiminkijoki (NW Finland), just before it enters the estuary, stored one week in the cold $\left(4^{\circ} \mathrm{C}\right)$, filtered through $0.2 \mu \mathrm{m}$ using Durapore 10 inch (Millipore) and Clariflow G 10 inch (Parker) cartridge filters and added to the mesocosms 2 days afterwards.

As there was a slight temperature gradient in the main test basin, the mesocosms were distributed only partially randomly. As shown in Fig. 1, the units were first randomly positioned into rows, but the respective manipulations (SW and SWR) were located at the same or adjacent row. The unit SW11 was reserved for instrumentation and it was excluded from all subsequent calculations and analysis due to possible contamination from instrumentation that was placed inside it.

The salinities of the SWR mesocosms were adjusted to the SW values by adding aquarium standard salt (Tropic Marin ${ }^{\circledR}$ ). Nitrate $\left(\mathrm{NO}_{3}^{-}\right)$and phosphate $\left(\mathrm{PO}_{4}^{3-}\right)$ were also adjusted to concentrations that did not limit bacterial growth in both series of mesocosms. The addition of river water caused large difference in dissolved silicate $\left(\mathrm{Si}(\mathrm{OH})_{4}\right)$ and DOC concentrations between the SW and SWR mesocosms, while nitrite $\left(\mathrm{NO}_{2}^{-}\right)$and ammonium $\left(\mathrm{NH}_{4}^{+}\right)$concentrations were similar (Table 1 ). Indeed, the differences in the mean starting conditions between SW and SWR were less than $10 \%$ (which was about the range of standard deviation within each series of mesocosms), except for $\mathrm{Si}(\mathrm{OH})_{4}$, DOC, and bacterial production derived from leucine (BP Leu) and thymidine (BP TdR) incorporation, which were about 4, 1.7, 1.3 and 1.2 times higher in SWR, respectively. a

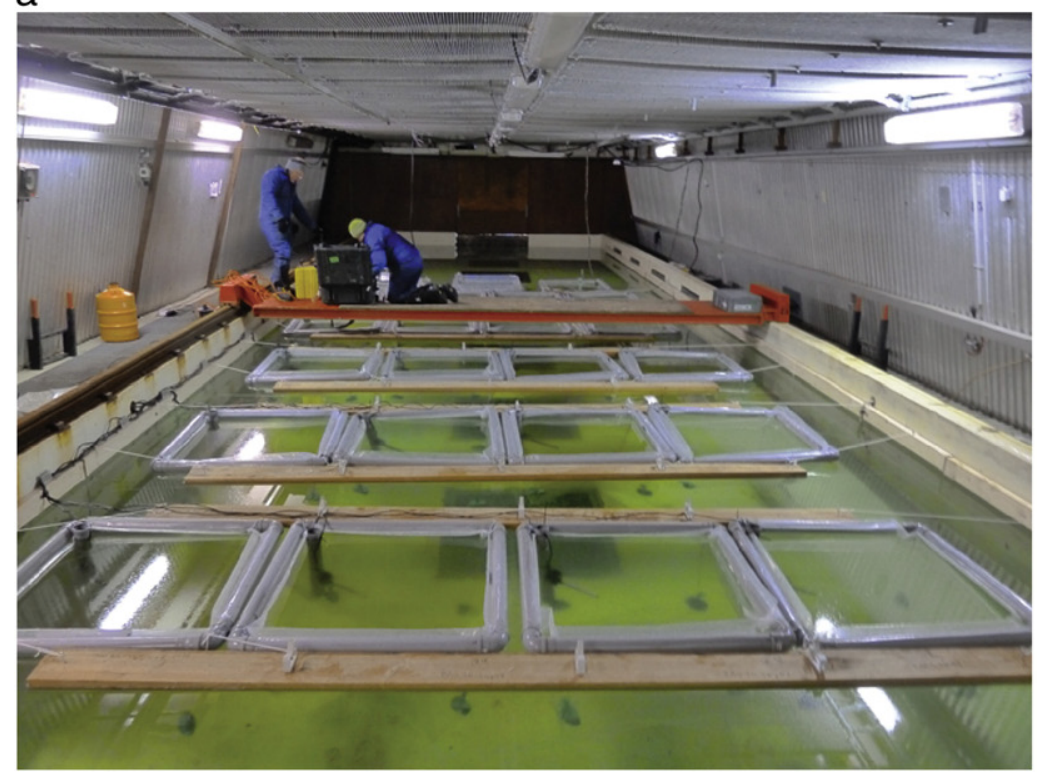

b

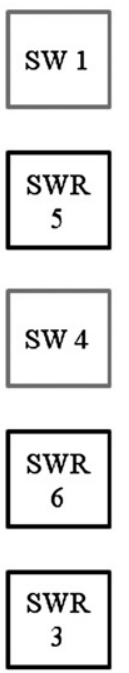

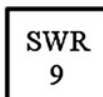
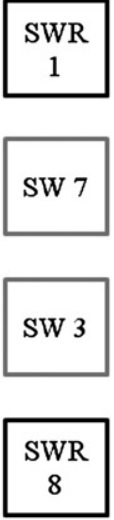

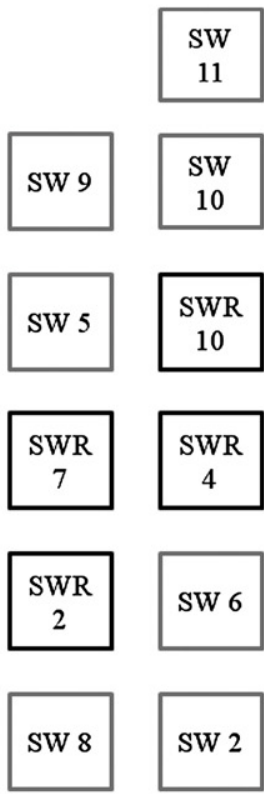

Row 6

$\uparrow$

Row 1

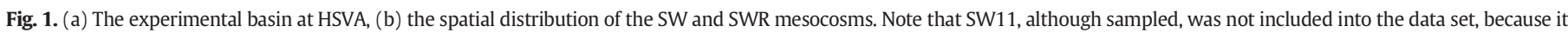
was reserved for continuous physical measurements. 
Table 1

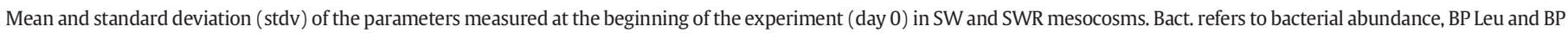
$\mathrm{TdR}$, to leucine-based and thymidine-based bacterial productions, respectively.

\begin{tabular}{|c|c|c|c|c|c|c|c|c|c|c|c|}
\hline & Salinity & TDN & $\mathrm{NO}_{3}^{-}$ & $\mathrm{NO}_{2}^{-}$ & $\mathrm{Si}(\mathrm{OH})_{4}$ & $\mathrm{PO}_{4}^{3-}$ & $\mathrm{NH}_{4}^{+}$ & DOC & Tot. bact. & Bact. prod. Leu & Bact. prod. TdR \\
\hline & & $\mu \mathrm{mol} \mathrm{L}^{-1}$ & $\mu \mathrm{mol} \mathrm{L}{ }^{-1}$ & $\mu \mathrm{mol} \mathrm{L}^{-1}$ & $\mu \mathrm{mol} \mathrm{L}{ }^{-1}$ & $\mu \mathrm{mol} \mathrm{L} \mathrm{L}^{-1}$ & $\mu \mathrm{mol} \mathrm{L}^{-1}$ & $\mu \mathrm{mol} \mathrm{L} \mathrm{L}^{-1}$ & $10^{6}$ cell mL $\mathrm{mL}^{-1}$ & $\mu \mathrm{g} \mathrm{C} \mathrm{L}^{-1} \mathrm{~h}^{-1}$ & $\mu g \mathrm{CL}^{-1} \mathrm{~h}^{-1}$ \\
\hline \multicolumn{12}{|l|}{ Mean } \\
\hline SW & 31.1 & 49.9 & 27.4 & 0.2 & 3.0 & 1.9 & 1.9 & 140.7 & 1.0 & 0.9 & 0.8 \\
\hline SWR & 30.6 & 51.3 & 27.2 & 0.2 & 12.3 & 1.9 & 1.9 & 245.8 & 0.9 & 1.2 & 0.9 \\
\hline \multicolumn{12}{|l|}{$S t d v$} \\
\hline SW & 0.0 & 6.6 & 4.4 & 0.0 & 0.7 & 0.1 & 0.1 & 4.3 & 0.2 & 0.1 & 0.2 \\
\hline SWR & 0.1 & 16.1 & 3.5 & 0.0 & 1.1 & 0.1 & 0.1 & 21.7 & 0.1 & 0.2 & 0.0 \\
\hline
\end{tabular}

The adjusted $\mathrm{NO}_{3}^{-}$and $\mathrm{PO}_{4}^{3-}$ concentrations (Table 1 ) are clearly higher than the maxima observed in the coastal Arctic Ocean (Codispoti et al., 2013; Dittmar et al., 2001), but were realistic compared to Southern Ocean values (e.g., Becquevort et al., 2009; Gleitz et al., 1994). DOC concentrations in both SW and SWR were consistent with the range observed in coastal Arctic Ocean (Dittmar and Kattner, 2003a) for a similar salinity as in the present study, and were also consistent with the range of DOC in surface waters of the Weddell Sea (50$60 \mu \mathrm{mol} \mathrm{L}^{-1}$ ) (Hansell et al., 2009; Lechtenfeld et al., 2014; Norman et al., 2011). Therefore, the findings of our experiment on the incorporation of DOC and the consequence on sea ice biogeochemistry may be pertinent to areas in both Arctic and Southern Oceans, where $\mathrm{NO}_{3}^{-}$ and $\mathrm{PO}_{4}^{3-}$ are not limiting for bacterial growth.

Ice was grown from day 0 to 14 , during which the air temperature was maintained at $-14{ }^{\circ} \mathrm{C}$, and then the air temperature was increased to $-1{ }^{\circ} \mathrm{C}$ to trigger a decay phase. The resulting changes in ice thickness are shown in Fig. 2 for each row of the mesocosms. Water and ice sample were collected at regular intervals from day 0 to day 1 , respectively (Table 2). Brine samples were collected from day 8 onwards, from $6 \mathrm{~cm}$ deep sackholes, when the ice was thick enough to avoid lateral infiltration of seawater. The brines were collected 15 to 30 min after drilling (depending on the percolation rate) using a portable peristaltic pump (Master Flex ${ }^{\circledR}, \mathrm{E} / \mathrm{S}$ portable sampler). Once the ice in a mesocosm was sampled it was considered to be compromised and not used again in the experiment.

A PVC tube was set at the corner of each mesocosm to maintain pressure equilibrium between the water and the atmosphere, and this was cleared of ice daily to relieve pressure and as a portal for sampling under-ice waters. Ice thickness was measured on all sampling days outside, but adjacent to, the mesocosms in order not to disturb the ice growth in the mesocosms before the sampling. The absence of active photoautotrophic organisms in ice and underlying waters was verified

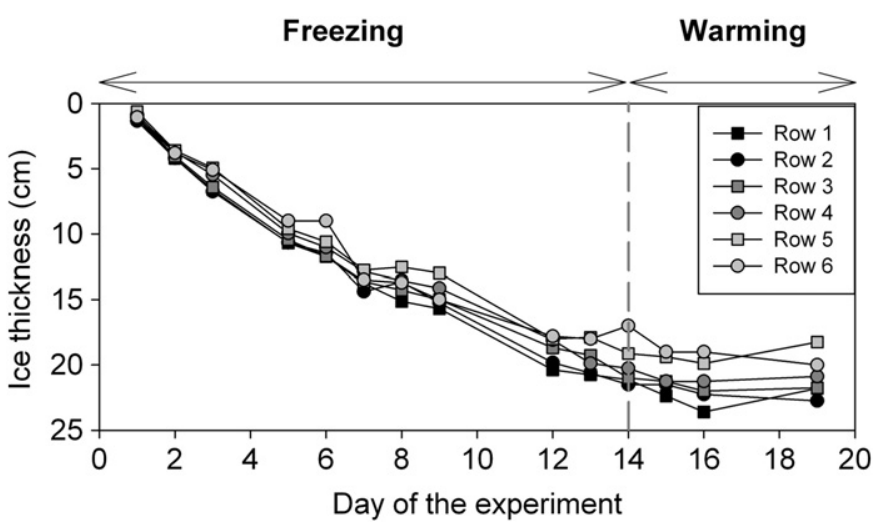

Fig. 2. Evolution of the ice thickness during the experiment. The ice thickness is given per row. Row 1 refers to the bottommost row of mesocosms (Fig. 1), while row 6 refers to the topmost row of mesocosms (Fig. 1). The vertical dashed line represents the day when we increased the air temperature from -14 to $-1{ }^{\circ} \mathrm{C}$ on all sampling days using epifluorescence microscopy, which would reveal the existence of functioning chloroplasts.

\subsection{Physical characteristics of the ice}

Ice temperature was measured using a calibrated probe (Testo 720 ) immediately after the extraction of the ice core. The probe was inserted into holes (matching the diameter of the probe) drilled perpendicular to the ice core axis with a depth resolution of $2 \mathrm{~cm}$. The precision of the probe was $\pm 0.1{ }^{\circ} \mathrm{C}$. Bulk ice salinity was measured using two approaches: first with melting of ice sections; and second with employing the approach of Cottier et al. (1999), which limits possible brine drainage and where ice was frozen with under-ice water, and then, sectioned. The latter method was used together with temperature measurements to derive brine volume fraction and brine salinity, following the relationships of Cox and Weeks (1983) (neglecting the air volume fraction). Measurements of the bulk ice salinity were performed on 2 or $4 \mathrm{~cm}$ vertical core sections. Salinities were measured with a portable conductivity meter (SEMAT Cond 315i/SET salinometer with WTW Tetracon 325 probe) on melted ice samples at room temperature. The precision was \pm 0.1 . This salinity was used to normalize the dissolved compounds to salinity (see Section 2.5).

For the brine calculations we assumed that the sea ice was permeable for a brine volume fraction exceeding 5\% (Golden et al., 1998), since the thin sections showed columnar ice structures (not shown). The derived brine salinity was comparable to the brine salinity measured on collected brine samples (data not shown). We therefore used temperature, bulk ice salinity, derived brine salinity and brine volume fraction to calculate the Rayleigh number ( $R a)$, which is a proxy for brine convection as described by Notz and Worster (2008). Theoretically, convection is possible in an ice layer (of a thickness $h$ ) when Ra exceeds 1 and decreases from the top to the bottom of that layer. However, critical Ra of 10 (Notz and Worster, 2008) and up to 8 (Zhou et al., 2013) was observed in experimental study and natural conditions, respectively. Because the calculation of Ra depends on the gradient of brine salinity, salt loss by drainage during ice core extraction, or the sampling resolution may lead to different Ra values. As there is currently no consensus on the critical value of Ra, we simply assume the critical Ra being 1 following the theoretical consideration.

Table 2

Days of the experiment with samplings and the associated sampled mesocosms. For all the mesocosms, available data in ice, under-ice water and brine are marked with a cross, while unavailable data are marked with a minus.

\begin{tabular}{lcccccccccc}
\hline Day of the experiment & 1 & 2 & 5 & 7 & 8 & 12 & 14 & 15 & 16 & 19 \\
\hline $\begin{array}{l}\text { Sampled mesocosms } \\
\text { (SW and SWR) }\end{array}$ & 2 & 3 & 6 & 8 & 4 & 7 & 1 & 5 & 9 & 10,11 \\
$\begin{array}{l}\text { Ice and under-ice water } \\
\text { Brine }\end{array}$ & $\times$ & $\times$ & $\times$ & $\times$ & $\times$ & $\times$ & $\times$ & $\times$ & $\times$ & $\times$ \\
& - & - & - & - & $\times$ & $\times$ & $\times$ & $\times$ & $\times$ & $\times$
\end{tabular}




\subsection{Nutrients and $D O C$}

Samples for inorganic nutrient analyses were stored frozen in $50 \mathrm{~mL}$ $\mathrm{PE}$ bottles. Inorganic nutrients $\left(\mathrm{NO}_{3}^{-}, \mathrm{NO}_{2}^{-}, \mathrm{NH}_{4}^{+}, \mathrm{PO}_{4}^{3-}\right.$ and $\left.\mathrm{Si}(\mathrm{OH})_{4}\right)$ were measured with an autoanalyzer system (Evolution III, Alliance Instruments) according to slightly modified seawater standard methods (e.g., Grasshoff et al., 1999; Kattner and Becker, 1991); $\mathrm{NH}_{4}^{+}$concentrations were measured according to Kérouel and Aminot (1997).

Samples for the determination of dissolved organic carbon (DOC) were stored frozen $\left(-20^{\circ} \mathrm{C}\right.$ ) in glass vials (Wheaton; precombusted at $500{ }^{\circ} \mathrm{C}, 5 \mathrm{~h}$ ) and determined by high temperature catalytic oxidation and subsequent non-dispersive infrared spectroscopy (TOC-VCPN, Shimadzu). After each batch of five samples, one reference standard (DOC-DSR, Hansell Research Lab, University of Miami, US), one ultrapure-water blank and one potassium hydrogen phthalate standard were measured. The accuracy of the DOC measurements was $\pm 5 \%$.

\subsection{Bacterial abundance and production}

Bacterial abundance was determined by flow cytometry after Gasol et al. (1999) and Gasol and Del Giorgio (2000). Samples for bacterial abundance were fixed with particle-free ( $0.2 \mu \mathrm{m}$-filtered) paraformaldehyde (final concentration of $1 \%$ ) and stored at $-80{ }^{\circ} \mathrm{C}$. Cell were stained with SYBR Green I (Molecular Probes) and counted on an LSR II flow cytometer (BD Biosciences, San Jose, USA) using a $488 \mathrm{~nm}$ laser. CountBright beads (Molecular Probes) with known concentration were added to each sample to calculate the measured volume. The bacterial counts were acquired for $1 \mathrm{~min}$, and the cell populations identified from bivariate plots of green fluorescence versus side scatter. Gating analysis was performed using FACS Diva software (BD Biosciences). The bacterial abundance counted (in cell $\mathrm{mL}^{-1}$ ) was calculated from the sample flow rates and number of events recorded. All samples were analyzed during one measurement session.

For the bacterial production measurements, samples containing a known amount of crushed ice and sterile-filtered seawater (Kaartokallio, 2004) were prepared as follows: Each intact 5-10 cm ice core section was crushed using a spike and electrical ice cube crusher. Approximately $10 \mathrm{~mL}$ of crushed ice was weighed in a scintillation vial. To better simulate the brine pocket salinity and ensure an even distribution of labeled substrate, $2-4 \mathrm{~mL}$ of sterile filtered (through $0.2 \mu \mathrm{m}$ filter) seawater from the sample bags were added to the scintillation vials. All the work was carried out in a cold room.

Bacterial production was measured immediately after sample collection using simultaneously the ${ }^{14} \mathrm{C}$-leucine (Kirchman et al., 1985) and ${ }^{3} \mathrm{H}$-thymidine (Fuhrman and Azam, 1980, 1982) incorporation methods. Two aliquots and a formaldehyde-fixed absorption blank were amended with L- $\left[\mathrm{U}-{ }^{14} \mathrm{C}\right]$ leucine (PerkinElmer, USA, specific activity $310 \mathrm{mCi} \mathrm{mmol}^{-1}$ ) and [methyl-3H] thymidine (PerkinElmer, USA, specific activity $20 \mathrm{Ci} \mathrm{mmol}^{-1}$ ). For thymidine, the concentrations were $30 \mathrm{nmol} \mathrm{L}^{-1}$ for all sample types; for leucine, the concentrations were $1000 \mathrm{nmol} \mathrm{L}^{-1}$ for ice samples, $330 \mathrm{nmol} \mathrm{L}^{-1}$ for water samples and $670 \mathrm{nmol} \mathrm{L}^{-1}$ for brine samples. The samples were incubated in the dark at $-0.6{ }^{\circ} \mathrm{C}$ on crushed ice in an insulated container according to the projected level of activity: ice samples were incubated 19-22 h, and water and brine samples $4-6 \mathrm{~h}$. The incubations were stopped by the addition of formaldehyde and samples were processed using the standard cold-TCA extraction and filtration procedure. Labeled macromolecules were collected on $0.2 \mu \mathrm{m}$ mixed cellulose ester membrane filters (Osmonics) and placed in clean scintillation vials. A Wallac WinSpectral 1414 counter and InstaGel (Perkin-Elmer) cocktail were used in scintillation counting. Bacterial production was calculated using a cell conversion factor of $2.09 \times 10^{18}$ cell mol $^{-1}$ (Smith and Clement, 1990), a cell volume of $0.3 \mu \mathrm{m}^{3}$ (Kaartokallio, 2004; Smith and Clement, 1990) and a carbon conversion factor of $0.12{\mathrm{pg} \mathrm{C} \mu \mathrm{m}^{-3}}^{-3}$ (Nagata and Watanabe, 1990; Pelegri et al., 1999) for thymidine; leucine-based bacterial production was calculated using a factor of $3.0 \mathrm{~kg} \mathrm{C} \mathrm{mol}{ }^{-1}$ (Bjornsen and Kuparinen, 1991).

\subsection{Data normalization and enrichment factor}

In order to compare the nutrient and DOC concentrations between SW and SWR mesocosms, we needed to remove the effect of bulk ice salinity on the nutrient and DOC concentrations, and to take into account the variability of the starting conditions between the individual mesocosms. Therefore the data was normalized to both salinity and the starting conditions, according to the following equation:

$X_{t_{-n}}^{m}=\overline{X_{0}} \times \frac{X_{t}^{m} \times \overline{S_{0}}}{S_{t}^{m} \times X_{0}^{m}}$

where

$X_{t_{-n}}^{m} \quad$ normalized concentration of the mesocosms $m$ for a given

time $t$

$X_{t}^{m} \quad$ concentration of the sample (water, brine or ice) for

mesocosm $m$ at time $t$

$S_{m}^{t} \quad$ salinity of the sample (water, brine or ice) in mesocosm $m$ at time $t$

$\overline{S_{0}} \quad$ mean salinity of the parent water at time 0 , which is 30.9

$X_{m}{ }^{0} \quad$ concentration in the parent water in mesocosm $m$ at time 0

$\overline{X_{0}} \quad$ mean start concentrations of SW (or SWR) if the sample was collected from SW (or SWR) mesocosms.

The data that have been normalized are referenced hereafter with "_n” after the name of the variable. Eq. (1) without $\overline{X_{0}}$ provides the enrichment factor.

\section{Results}

\subsection{Ice thickness}

The ice thickness increased until day 16 , reaching a maximum of $24 \mathrm{~cm}$, and then stabilized or slightly decreased towards the end of the experiment (Fig. 2). Overall, there was a general trend in the basin where the ice thickness decreased from row 1 to row 6 . The difference was particularly obvious at the end of the experiment $(4.5 \mathrm{~cm}$ of difference between row 1 and row 5 on day 19). The maximum difference of ice thickness between adjacent rows was $2.6 \mathrm{~cm}$. The majority of mesocosms sampled on the same day were generally located on the same row (e.g., SW8 and SWR8) or adjacent rows (e.g., SW3 and SWR3) (Fig. 1), which minimized the influence of this cross-basin gradient.

\subsection{Physical properties of the ice}

There was an increasing temperature gradient between the top and the bottom of the ice from day 1 to 15 (the freezing phase). In the subsequent melting phase the ice temperatures became more vertically homogeneous, approaching $-1.8^{\circ} \mathrm{C}$ on day 19 (Fig. 3).

The salinity of the bulk ice was homogeneous until day 3 , before developing a typical C-shape profile with a higher salinity at the top and the bottom of the ice compared to the ice interior. From day 3 to 15 , the ice bulk salinity ranged between 4.6 and 23.5. In the bottom ice horizons salinities of the SW ice were up to 3.9 salinity units higher than those of SWR between day 8 and day 14. From day 15 onwards, the salinity decreased in both the top and the bottom and ranged between 4.6 and 10.5 .

The brine volume fraction remained above $5 \%$ during the whole experiment in both SW and SWR mesocosms. The bottom of the ice always 
SW
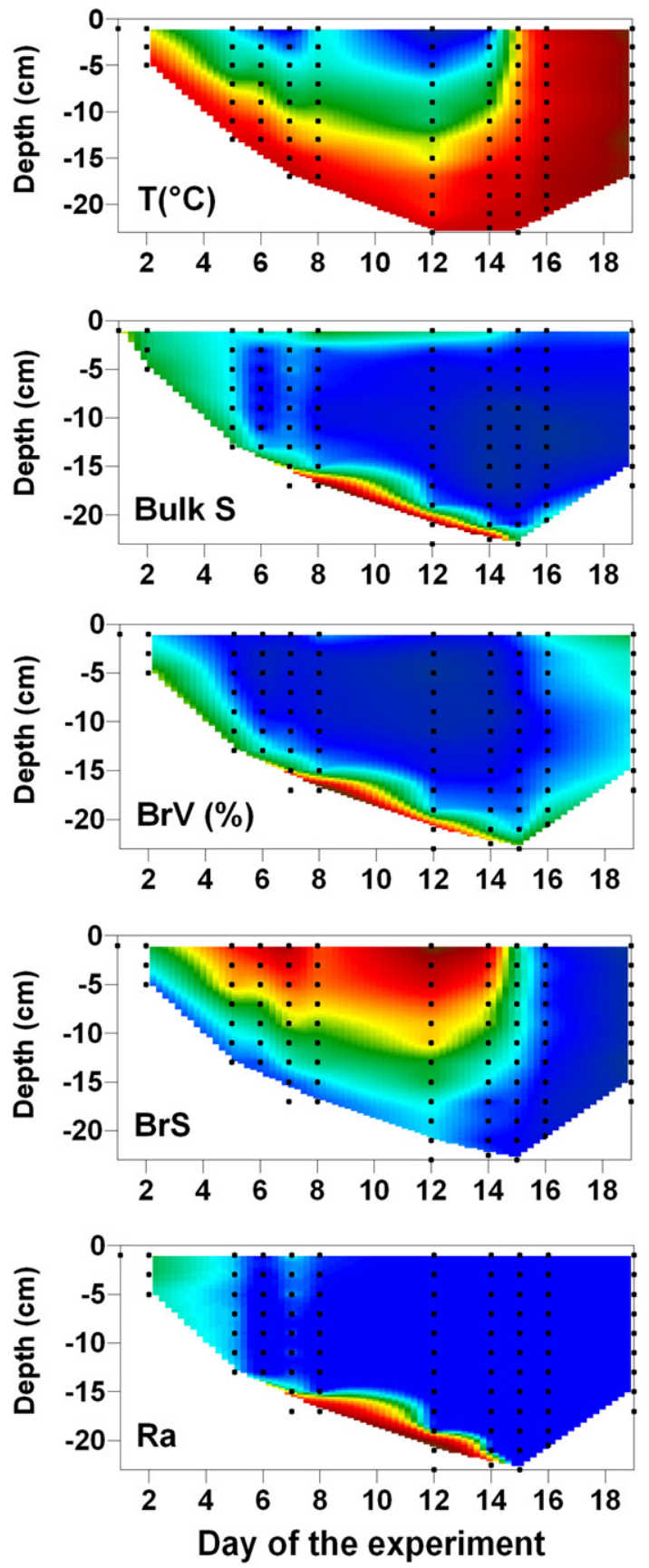

SWR
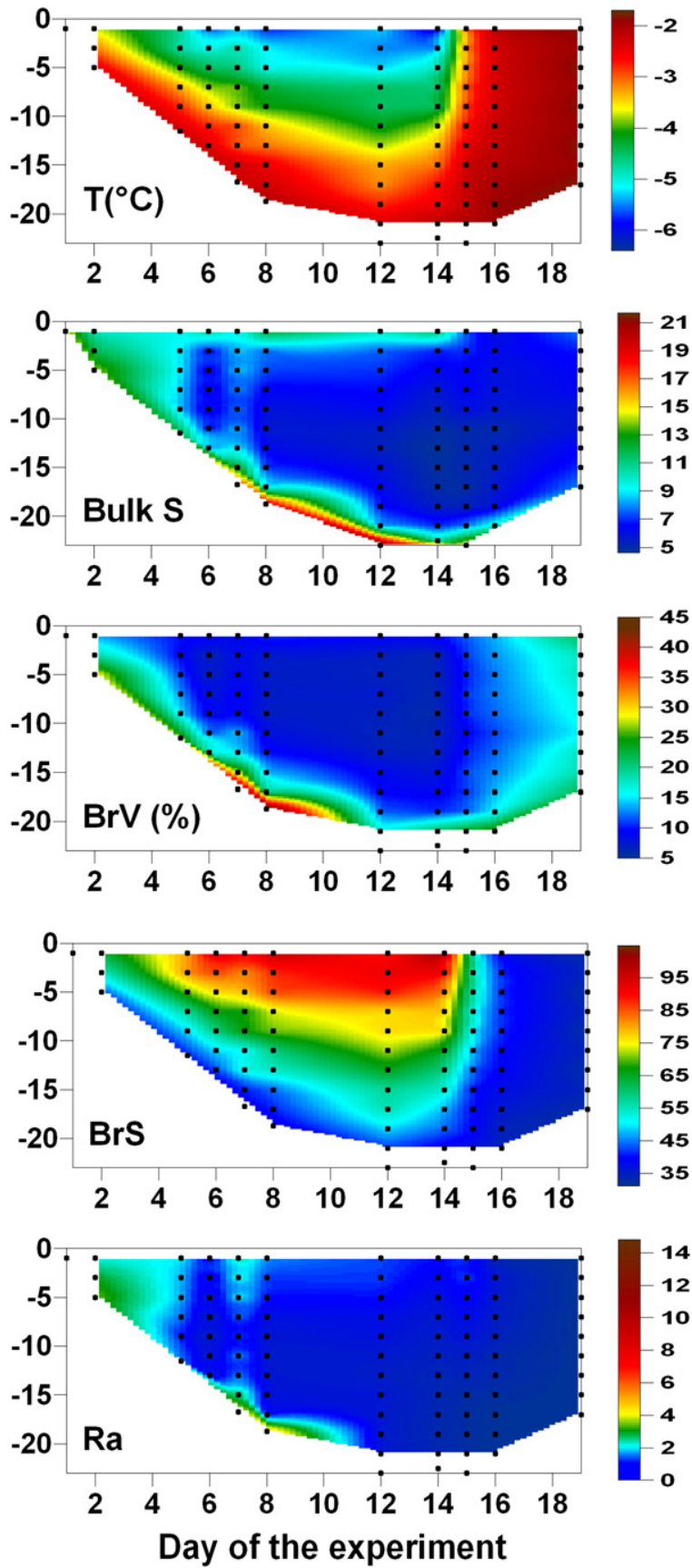

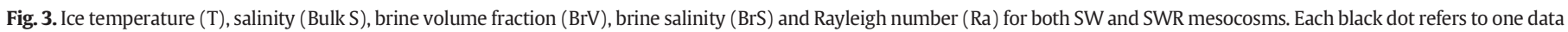
point, the color in between results of interpolation.

had a larger brine volume fraction compared with the upper ice layers, except between day 17 and 19 when the estimated brine volume fractions were homogeneous over the whole ice cover. As for the bulk ice salinity, the brine volume fractions at the bottom of SW ice were higher than in SWR between day 8 and 14 .

The calculated brine salinities decreased from the top to the ice bottom from day 1 to 16 in both SW and SWR mesocosms. During the final melting stage, brine salinities became more homogeneous throughout the ice cover. On day 19, they approached 32, which was lower than the salinity in the under-ice water (36.7).

The temporal changes of Ra were similar to those in the bulk salinity: Ra slightly exceeded 1 throughout the ice of both SW and SWR between day 1 and 3 . From day 3 to 15 , there was a sharp contrast of the Ra between the ice bottom and the ice interior: Ra was as high as 17.9 in the bottom of SWR and contrasted with the 0.1 value in the ice interior. The differences in salinity and brine volume fractions at the ice bottom between SWR and SW were particularly evident in Ra: On day 8, when the difference in salinity was 3.9, the difference in Ra reached 7.3 in both experiments. Ra dropped below 0.5 on day 15 and was equal to 0 at all ice depths on day 19.

It is worth noting the difference of up to 3.9 in salinity and up to 7.3 in Ra between SW and SWR in the bottom ice layer on day 8. We observed a salinity of 23.5 in the ice bottom of SW, which is higher than the salinity measured on ice blocks that were obtained under similar conditions (salinity of 9 in Cottier et al., 1999). However, because of the continuum of salinity between the ice and the under-ice water 
sw

Day of the experiment
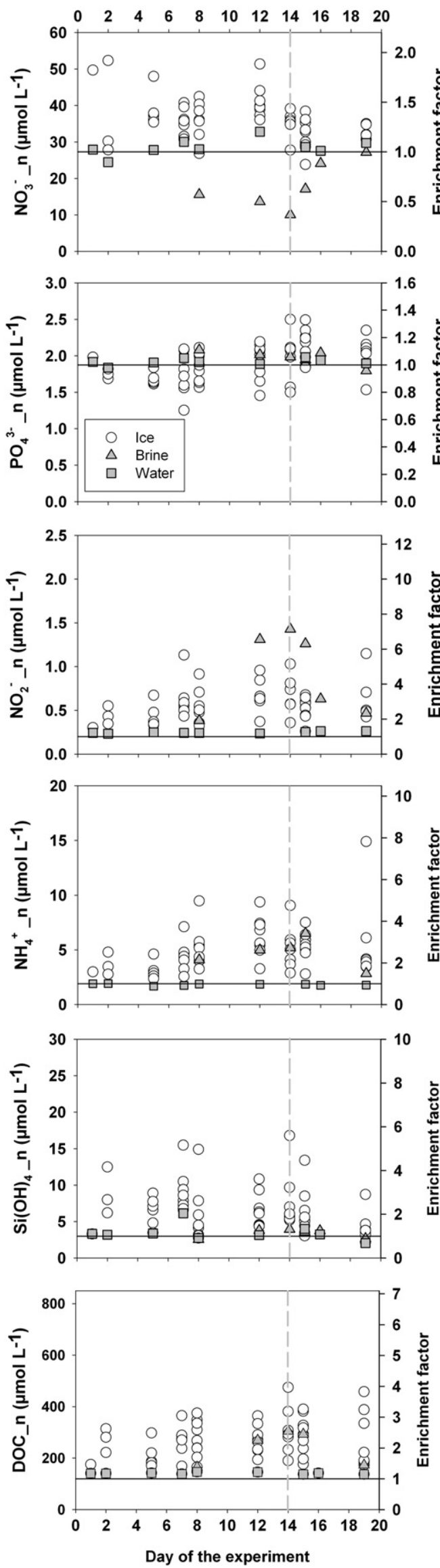

SWR

Day of the experiment
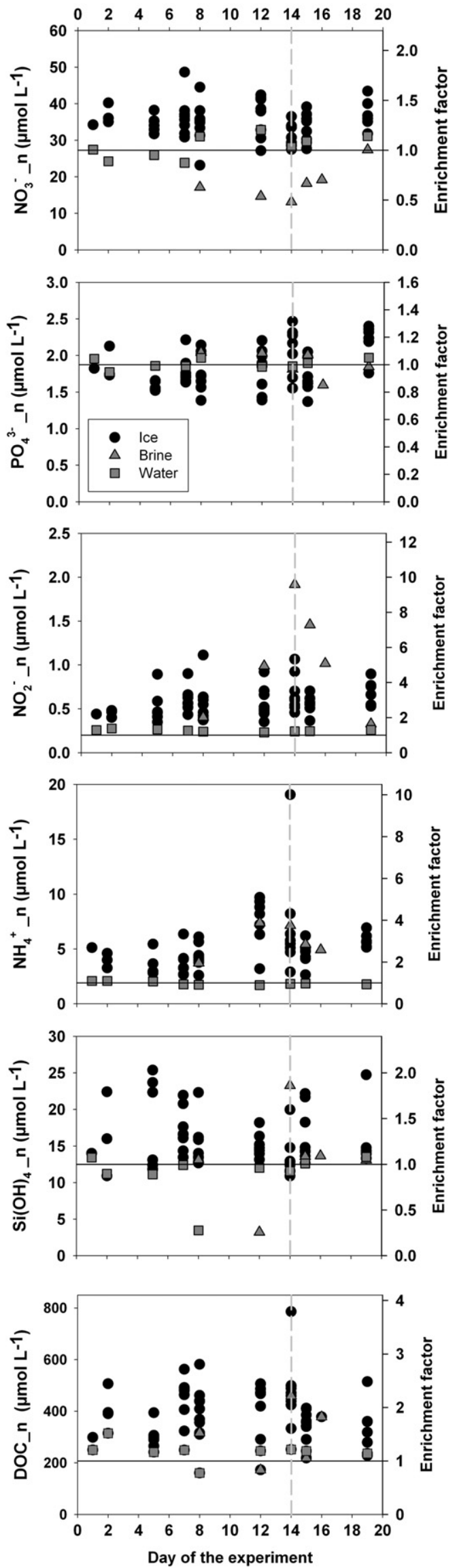
(Notz et al., 2005), a salinity of 23.5 may be realistic, since it is still lower than 30.9 , the salinity of the under-ice water. Further, the resolution of the cutting was different for the last layer $(2 \mathrm{~cm}$ for SW but $3 \mathrm{~cm}$ for SWR). Because ice salinity increased sharply in the last few centimeters of the ice (Notz et al., 2005), lower resolution sampling naturally results in higher ice salinities. The differences in salinity resulted in a difference in Ra (Vancoppenolle et al., 2013), but does not influence our interpretation since the qualitative interpretation of Ra (e.g., Zhou et al., 2013) is sufficient to describe the brine dynamics.

\subsection{Nutrients and $D O C$}

Fig. 4 presents the normalized concentrations of the dissolved compounds in ice, brine and seawater (and the corresponding EF) for both SW and SWR mesocosms. If the nutrients had behaved conservatively with respect to salinity, they would exhibit an EF of 1. Therefore, Fig. 4 shows that, with the exception of the dissolved compounds in the under-ice water and $\mathrm{PO}_{4}^{3-}{ }_{-} \mathrm{n}$ in ice, all nutrients in ice and brine were not conservative, i.e., they significantly differ from an EF of 1 (t-test, $\mathrm{p}<0.001$ ). This observation was true for both SW and SWR mesocosms.

For $\mathrm{NO}_{3}^{-} \_\mathrm{n}, \mathrm{NO}_{2}^{-} \_\mathrm{n}$ and $\mathrm{NH}_{4}^{+} \_\mathrm{n}$, the EFs varied similarly in both treatments: $\mathrm{NO}_{3}^{-}$n in ice approached an EF of 2 for both mesocosms. $\mathrm{NO}_{2}^{-} \_\mathrm{n}$ and $\mathrm{NH}_{4}^{+} \_\mathrm{n}$ in ice approached an $\mathrm{EF}$ of 6 , but local $\mathrm{NO}_{2}^{-} \_\mathrm{n}$ in brine and $\mathrm{NH}_{4}^{+}$_n in ice reached an $\mathrm{EF}$ up to 10 in SWR. This contrasts with the $\mathrm{NO}_{3}^{-} \_\mathrm{n}$ in brine that was only half of the concentration of the starting water concentrations ( $\mathrm{EF}=0.5$ ).

The normalized dissolved compounds did not show obvious changes over time, with the exception of $\mathrm{NO}_{2}^{-} \_n$, which increased until day 7 and then remained constant. $\mathrm{NH}_{4}^{+} \_\mathrm{n}$ and DOC_n increased until day 19 in SW, but peaked already on day $12-14$ and thereafter decreased in SWR.

In contrast to all the previous dissolved compounds, $\mathrm{Si}(\mathrm{OH})_{4} \mathrm{n}$ and DOC_n had different EFs in both treatments: although $\mathrm{Si}(\mathrm{OH})_{4}$ and DOC concentrations were both higher in SWR than in SW in the parent waters, their EFs in ice were lower in SWR than SW (Fig. 5). In addition, both compounds show a decreasing EF from the top to the bottom of the ice, where the EFs generally approached a value of 1 (Fig. 5).

\subsection{Bacterial abundance and production}

In both mesocosm series, bacterial abundance in ice (ca. 0.1 to

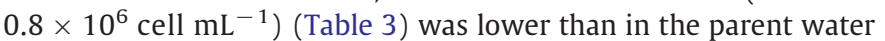
$\left(0.9\right.$ to $1.0 \times 10^{6}$ cell $\mathrm{mL}^{-1}$ ) (Table 1$)$. Fig. 6 shows the temporal evolution of bacterial abundance and its vertical variability. During the ice growth phase (day 0 to 14), bacterial abundance was high at all depths from day 0 to day 2 , then decreased in the ice interior, but remained in the bottom of the ice in the beginning and in the ice. During the ice decay phase, bacterial concentrations decreased, and the ice bottom maximum observed during ice growth phase disappeared.

In order to compare the bacterial activity in both treatments, without the effect of bacterial abundance, we compared both Leu and TdR incorporation per cell (Fig. 6), rather than per volume of ice. It is evident that (1) all the values in ice were lower than those in the parent water at the starting conditions, but (2) both Leu and TdR incorporation per cell increased from day 14 onwards in parallel with the increase of air temperature, and (3) they were both higher in SWR than in SW.

For comparison with the literature, we also calculated bacterial production from both Leu and TdR incorporation. Overall Leu-based bacterial production rates ranged between 0.04 and $0.47 \mu \mathrm{C} \mathrm{L} \mathrm{L}^{-1} \mathrm{~h}^{-1}$ and TdRbased bacterial production rates between 0.01 and $0.47 \mu \mathrm{C} \mathrm{L} \mathrm{L}^{-1} \mathrm{~h}^{-1}$ (Table 3). The median Leu/TdR ratio was 44 in SW and 26 in SWR.

\section{Discussion}

\subsection{Physical imprints on nutrient incorporation}

There were no significant differences in the physical parameters of SW and SWR (Fig. 3), except small differences in ice thickness (Fig. 2), and the vertical changes of the physical properties of the ice from growth to decay were consistent with observations from Arctic sea ice (Carnat et al., 2013; Zhou et al., 2013). We identified 3 main stages in brine dynamics, which affected the incorporation of nutrients. From day 1 to day 2, the homogeneous bulk salinity throughout the ice indicates that convection had occurred. However, sea ice has to reach a thickness of about $5 \mathrm{~cm}$ for gravity drainage to occur (Worster and Wettlaufer, 1997). Our samples were all thinner than $5 \mathrm{~cm}$. We therefore suggest that we may have artificially induced convection while sawing the ice during the sampling. From day 2 to day 15 , the Ra profile only suggests brine convection at the ice bottom, although the brine volume fraction remained above $5 \%$ at all depths, i.e., permeable (Golden et al., 1998). Finally, from day 15 to the end of the experiment, the increase of air temperature (Fig. 2) increased the ice temperature. As a consequence, brine salinity decreased, Ra dropped below 1 and brine convection stopped.

It is noteworthy that we did not observe full-depth brine convection at the beginning of the warming phase, as found in natural ice covers by Carnat et al. (2013) and Zhou et al. (2013). This is likely to be a result of the temperature not being low enough at the ice surface to promote a strong brine salinity gradient (a requirement for full-depth brine convection). Alternatively, full-depth convection occurred, but we could not observe it, because it was transient and rapid in comparison to the frequency of our sampling.

The impact of brine dynamics on nutrient distribution was clear (Fig. 5): because convection favors the exchange of nutrients between the brine and the under-ice water (Vancoppenolle et al., 2010), the EF of $\mathrm{Si}(\mathrm{OH})_{4}$ approached 1 in the bottom of the ice, but increased towards the top of the ice, where convection was limited (Ra close to 0.1 ). Ice melt implies an addition of freshwater to the brine, which will dilute the nutrient concentrations; however, brine dilution was not seen in our data, since they were all double-normalized (including normalization to salinity).

A solute that is solely subject to physical incorporation should behave conservatively with respect to salinity (i.e., concentrations evolve in parallel with salinity on a dilution curve (Thomas et al., 2010)). If other processes such as biological uptake or regeneration occur, solute concentrations will deviate from the dilution curve, resulting in an EF that differs from 1. All measured parameters had an ice EF between 1.1 and 1.8 during initial freezing (day 1 to 2 ) indicating a net production or preferential incorporation (relative to salinity). This is in agreement with earlier results from natural sea ice for most of the nutrients, as opposed to other major ions (Meese, 1989).

One explanation is that the direct incorporation favors the accumulation of dissolved compounds in sea ice, although this has only been shown for DOC (Giannelli et al., 2001; Müller et al., 2013) and $\mathrm{NH}_{4}^{+}$ (Zhou et al., 2013). This explanation is at least true for fluorescent DOM, since optical measurements performed during this experiment showed a selective incorporation of different fluorescent DOM fractions in sea ice (i.e., amino-acid-like and humic-like fluorescent DOM) (Jørgensen et al., submitted for publication). Our range of EF for DOC is consistent with the one previously presented for artificially produced DOM (1.0-2.7) under similar ice growth conditions (Müller et al., 2013).

Another potential explanation for the EFs above 1 is that the compounds were initially incorporated as particulate matter, and then converted to DOM after incorporation. This could occur if organisms and

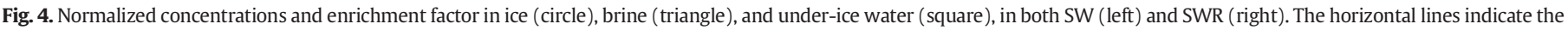

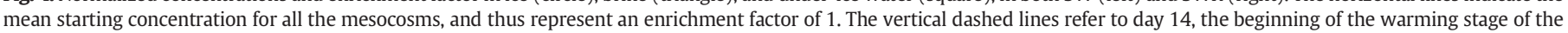
experiment. 

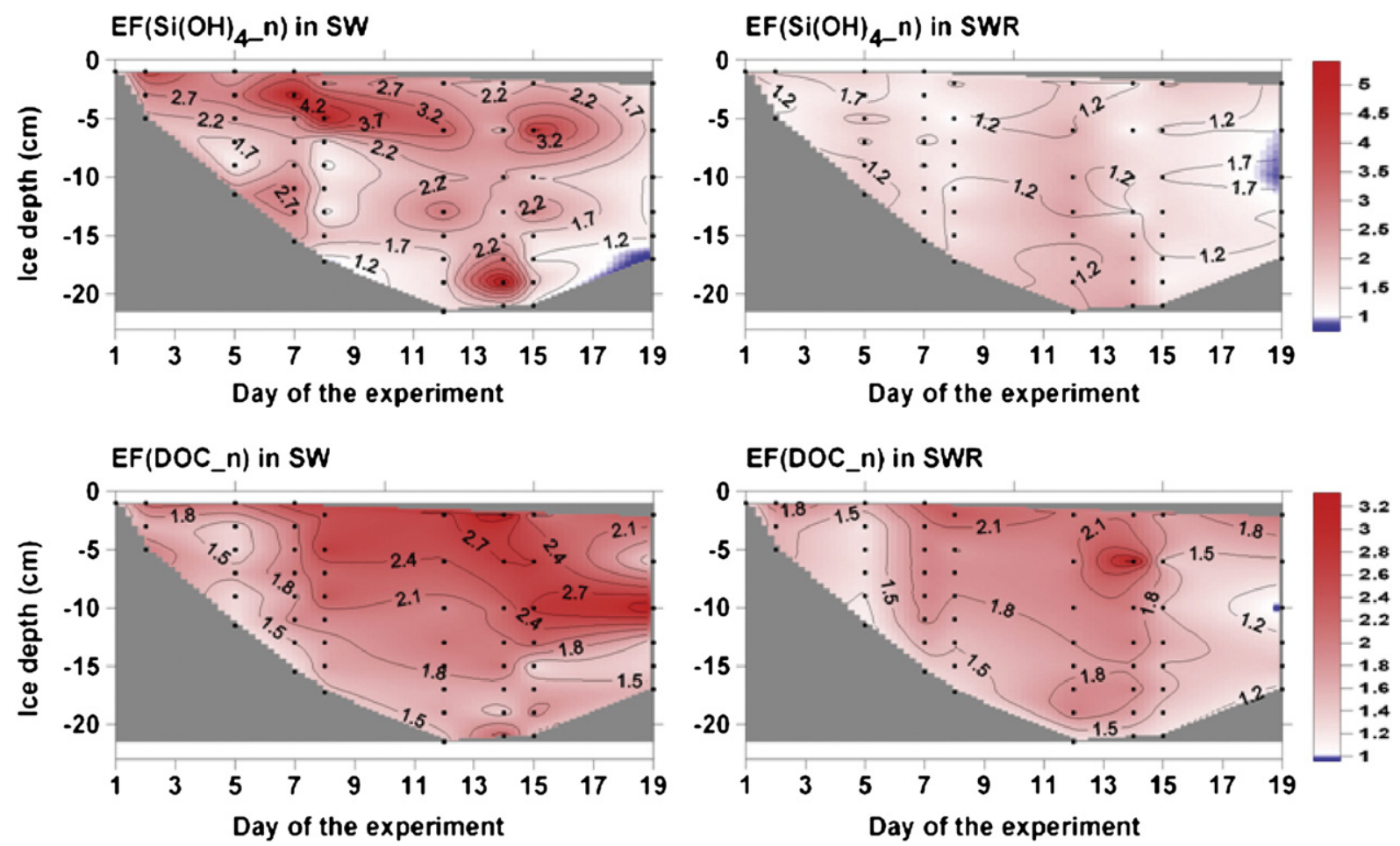

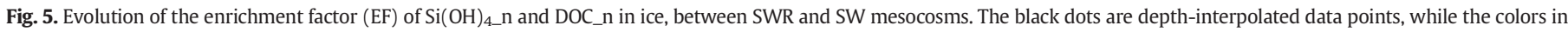
between are interpolations (natural neighbor).

particulate organic matter (POM) were incorporated in the ice; algal and bacterial lyses and POM degradation may have then increased the concentrations of the dissolved compounds in sea ice, leading to EFs above 1. DOC could originate from the degradation of POM (Thomas et al., 1995), and $\mathrm{Si}(\mathrm{OH})_{4}$, from death algal cell. Although no functioning chloroplast was observed, we cannot exclude the possible existence of dead algal cell, their fragments, and other POMs in the parent water, because the seawater had not been filtered (see Material and methods).

$\mathrm{NO}_{3}^{-}$showed a negative $\mathrm{EF}$ in brine, in contrast to all the other compounds, suggesting either a consumption of $\mathrm{NO}_{3}^{-}$in sea ice or an adsorption of $\mathrm{NO}_{3}^{-}$to the ice crystals (Bartels et al., 2002) (i.e., parts of the $\mathrm{NO}_{3}^{-}$ were not collected in brine). Potential pathways for $\mathrm{NO}_{3}^{-}$consumption are $\mathrm{NO}_{3}^{-}$respiration to $\mathrm{NO}_{2}^{-}$(Fripiat et al., 2014) and/or denitrification (Kaartokallio, 2001; Rysgaard et al., 2008) with production of $\mathrm{NO}_{2}^{-}$, $\mathrm{N}_{2} \mathrm{O}$ and $\mathrm{N}_{2}$. However, $\mathrm{NO}_{2}^{-}$in ice (Table 3) or $\mathrm{N}_{2} \mathrm{O}$ in brine (data not shown) did not increase significantly, suggesting that $\mathrm{NO}_{3}^{-}$reduction and denitrification were minor. Therefore, the adsorption of $\mathrm{NO}_{3}^{-}$is more likely the factor responsible for the observed negative EF. This is also coherent with the observation of positive $\mathrm{NO}_{3}^{-} \mathrm{EFs}$ in the ice.

\subsection{Bacterial growth, production and imprints on nutrient concentrations}

Our Leu- and TdR-based bacterial production estimates are convergent, pointing to the reliability of the results. Overall BP Leu and TdR in ice were low, but were comparable to those of Kuparinen et al. (2011) obtained on predator-free batch cultures from melted 2-weekold sea ice. The bacterial abundance and ice salinities were in the same range to other studies measuring bacterial production in sea ice in the Southern Ocean (Grossmann and Dieckmann, 1994; Helmke and Weyland, 1995), the Arctic Ocean (Kaartokallio et al., 2013; Nguyen and Maranger, 2011) and the Baltic Sea (Kuparinen et al., 2007). Unlike many studies done in natural sea ice, algae and other typical larger sea ice organisms were absent in our experiment, which may have led to lower bacterial production, since ice algae may be a source of autochthonous DOM in ice (Thomas et al., 2001).

Overall, cell-specific Leu and TdR were lower in ice than in parent water, indicating different physiological adaptations required in these two adjacent environments. The dynamics in bacterial activity appeared to be associated with three different stages in cell-specific

Table 3

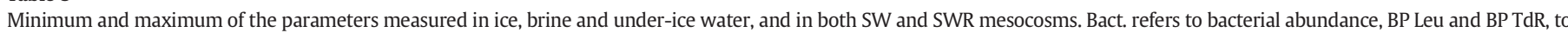
leucine-based and thymidine-based bacterial productions, respectively.

\begin{tabular}{|c|c|c|c|c|c|c|}
\hline & \multicolumn{2}{|l|}{ Ice } & \multicolumn{2}{|l|}{ Brine } & \multicolumn{2}{|c|}{ Under-ice water } \\
\hline & SW & SWR & SW & SWR & SW & SWR \\
\hline Salinity $^{\mathrm{a}}$ & $5.3-15.1$ & $5.9-14.7$ & $36.0-104.6$ & $36.6-100.4$ & $31.1-39.8$ & $29.0-39.6$ \\
\hline $\mathrm{NO}_{3}^{-} \mu \mathrm{mol} \mathrm{L}^{-1}$ & $4.9-21.9$ & $5.4-16.7$ & $29.3-41.6$ & $28.8-41.5$ & $26.0-48.6$ & $25.6-43.5$ \\
\hline $\mathrm{NO}_{2}^{-} \mu \mathrm{mol} \mathrm{L}^{-1}$ & $0.1-0.3$ & $0.1-0.3$ & $0.5-4.4$ & $0.4-5.4$ & 0.3 & 0.3 \\
\hline $\mathrm{Si}(\mathrm{OH})_{4} \mu \mathrm{mol} \mathrm{L}^{-1}$ & $0.7-5.3$ & $2.4-7.9$ & $4.9-12.8$ & $13.7-68.0$ & $2.9-6.6$ & $11.5-19.8$ \\
\hline $\mathrm{PO}_{4}^{3-} \mu \mathrm{mol} \mathrm{L}^{-1}$ & $0.3-1.0$ & $0.3-0.9$ & $2.2-6.8$ & $2.1-6.3$ & $1.9-2.6$ & $1.8-2.5$ \\
\hline $\mathrm{NH}_{4}^{+} \mu \mathrm{mol} \mathrm{L}-1$ & $0.8-3.1$ & $0.8-3.8$ & $3.7-16.8$ & $7.5-25.5$ & $1.8-2.4$ & $1.9-2.4$ \\
\hline $\mathrm{DOC} \mu \mathrm{mol} \mathrm{L}^{-1}$ & $32-131$ & $46-170$ & $209-892$ & $602-1334$ & $145-179$ & $247-347$ \\
\hline Tot. bact. $10^{6}$ cell $\mathrm{mL}^{-1}$ & $0.14-0.76$ & $0.17-0.84$ & $0.74-3.59$ & $1.51-4.23$ & $0.77-1.96$ & $0.84-2.72$ \\
\hline Bact. prod. Leu $\mu g \mathrm{C} \mathrm{L}^{-1} \mathrm{~h}^{-1}$ & $0.04-0.37$ & $0.06-0.47$ & 0.1 & $0.18-0.90$ & $0.61-1.25$ & $0.61-1.25$ \\
\hline Bact. prod. TdR $\mu \mathrm{g} C \mathrm{~L}^{-1} \mathrm{~h}^{-1}$ & $0.01-0.37$ & $0.03-0.47$ & 0.04 & $0.23-0.72$ & $0.21-1.08$ & $0.53-1.87$ \\
\hline
\end{tabular}

\footnotetext{
a Extraction of the ice following Cottier et al. (1999).
} 

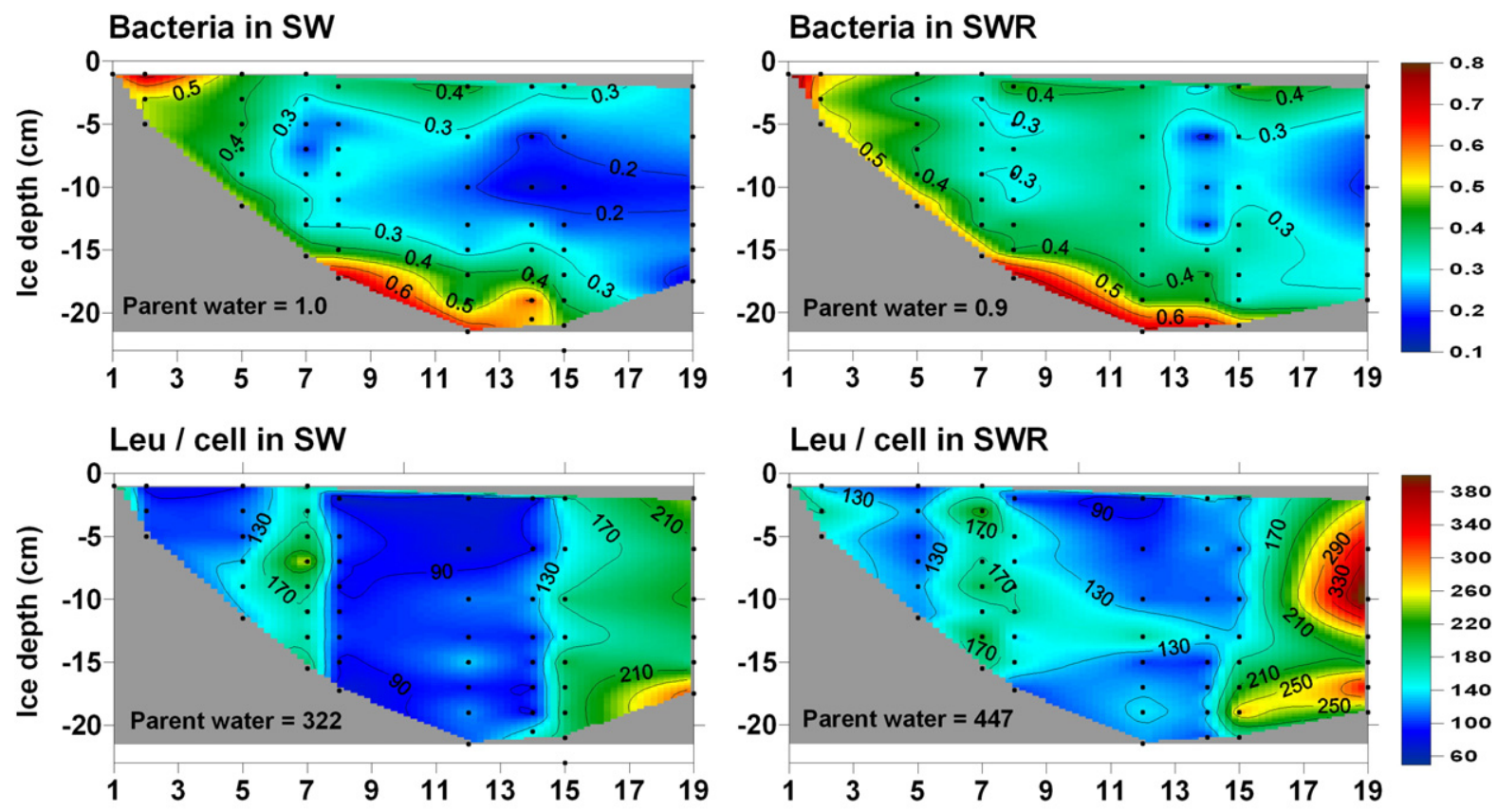

TdR / cell in SW

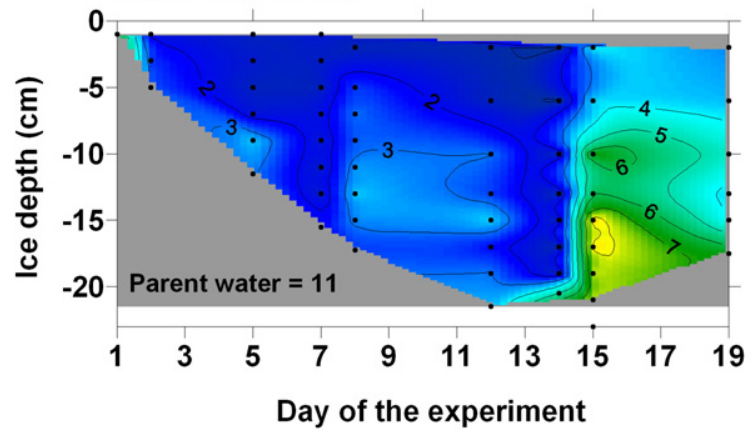

\section{TdR / cell in SWR}

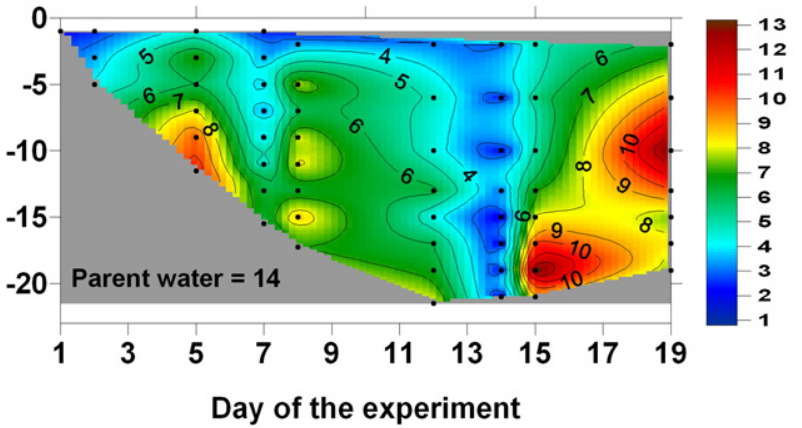

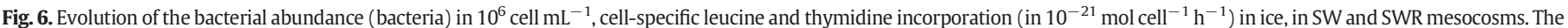

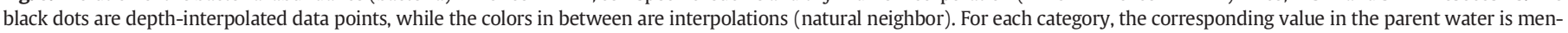
tioned for comparison $\left(10^{6}\right.$ cell $\left.\mathrm{mL}^{-1}\right)$.

Leu and TdR and bacterial abundance. At the beginning of the experiment, the majority of bacteria in ice were probably not wellacclimated to the sea ice environment and possibly undergoing a community shift (Eronen-Rasimus et al., 2014), resulting in a decrease in abundance throughout the ice before day 7 . After day 7 , cell-specific Leu and TdR were generally stable, but bacterial abundance increased in the bottom ice sections and decreased in the ice interior, pointing to active bacterial growth in the lower ice layers being also subject to brine convection before day 15 . After day 15 , corresponding to the onset of the melting phase, bacterial abundance decreased throughout the ice column and a sharp increase in cell-specific Leu and TdR occurred. This points to a direct effect of physical changes on the bacterial physiology, most likely to be initiated by a sudden change in brine salinity and ice temperature or decreasing nutrient supply due to brine stratification. Brine dilution and direct cell loss from bottom ice during the melting phase could explain the decrease of bacterial abundance.

While cell-specific Leu showed a similar pattern in both treatments, TdR was higher in SWR (compared to SW) in both ice and parent water. This indicates that DOC addition had a positive impact on bacterial growth, which is also in agreement with the slightly higher bacterial abundance and overall higher bacterial production in SWR series (Table 3).

Bacterial activity may have impacted $\mathrm{NH}_{4}^{+}$and $\mathrm{NO}_{2}^{-}$concentrations in sea ice, but had no notable effect on $\mathrm{NO}_{3}^{-}$and DOC. Indeed, $\mathrm{NH}_{4}^{+}$ and $\mathrm{NO}_{2}^{-}$further accumulated in sea ice on day 7, after their physical incorporation into sea ice, in SW and SWR. Although the accumulation of $\mathrm{NH}_{4}^{+}$and $\mathrm{NO}_{2}^{-}$likely indicates bacterial remineralization, the highest concentrations of $\mathrm{NH}_{4}^{+}$and $\mathrm{NO}_{2}^{-}$were not found at the bottom of the ice, where bacterial concentration was the highest, but rather at the surface ice layer (not shown). $\mathrm{NH}_{4}^{+}$and $\mathrm{NO}_{2}^{-}$thus present a vertical EF profile similar to those of DOC (Fig. 5), with decreasing EF from the top to the bottom, in spite of bacterial remineralization. We interpret this to be the result of the interaction between bacterial remineralization and brine convection: because brine convection tends to remove the additional $\mathrm{NH}_{4}^{+}$and $\mathrm{NO}_{2}^{-}$, the accumulation of $\mathrm{NH}_{4}^{+}$and $\mathrm{NO}_{2}^{-}$was only obvious at the surface ice layers, where convection was limited.

The remineralization of DOC was almost negligible because bacterial productions were low in comparison to the large pool of DOC in sea ice. Indeed, median bacterial production was $0.16 \mu \mathrm{C} \mathrm{L} \mathrm{L}^{-1} \mathrm{~h}^{-1}$, which is

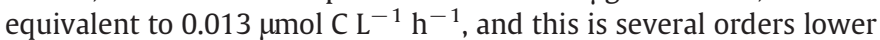
than the DOC concentrations (up to $170 \mu \mathrm{mol} \mathrm{L}^{-1}$ ) (Table 3). As a consequence, the difference in bacterial productions could not explain the difference in the EFs of DOC between SW and SWR.

\subsection{The particular cases of $\mathrm{Si}(\mathrm{OH})_{4}$ and $\mathrm{DOC}$}

All the dissolved compounds showed similar EF in both SW and SWR with the exception of $\mathrm{Si}(\mathrm{OH})_{4}$ and DOC. We did not expect a difference 
in the brine convection as a possible explanation since the physical conditions were comparable between the two treatments. Also, bacterial production might not have affected $\mathrm{DOC}$ and $\mathrm{Si}(\mathrm{OH})_{4}$ concentrations significantly, as it was too low in comparison to the large DOC pool, and because bacterial activity is not known to affect $\mathrm{Si}(\mathrm{OH})_{4}$.

A possible explanation for the difference in $\mathrm{EF}$ for $\mathrm{Si}(\mathrm{OH})_{4}$ is the degradation of algal cell that were incorporated into the ice (see Section 4.1), which may have induced a bias in the EF. To verify the hypothesis of particulate silicate (PSi) conversion into $\mathrm{Si}(\mathrm{OH})_{4}$ (DSi), we calculated the deviation of mean $\mathrm{Si}(\mathrm{OH})_{4}$ in ice at the mean ice salinity of 8 from the dilution curve: The mean $\mathrm{Si}(\mathrm{OH})_{4}$ in sea ice was 1.9 and $4.3 \mu \mathrm{mol} \mathrm{L}^{-1}$ in SW and SWR respectively, while it should be 0.8 and $3.2 \mu \mathrm{mol} \mathrm{L}{ }^{-1}$ if it behaved conservatively. Thus, the deviation from the dilution curve was $1.1 \mu \mathrm{mol} \mathrm{DSi} \mathrm{L}^{-1}$ for both SW and SWR. This deviation is the additional $\mathrm{Si}(\mathrm{OH})_{4}$ that we attribute to PSi degradation. Because DSi_n increased considerably on day 2 and then remained constant, the PSi degradation rate should approach $0.55 \mu \mathrm{mol} \mathrm{L} \mathrm{L}^{-1} \mathrm{~d}^{-1}$ and then became negligible. This PSi degradation rate corresponds to a dissolution rate constant of PSi of $0.15 \mathrm{~d}^{-1}$ (assuming a first order reaction). Similar PSi degradation rate $\left(0.52-0.6 \mu \mathrm{mol} \mathrm{L}{ }^{-1} \mathrm{~d}^{-1}\right.$ (Fripiat et al., 2009) ) and dissolution rate constants $\left(0.16 \mathrm{~d}^{-1}\right.$ (Demarest et al., 2009), $0-0.2 \mathrm{~d}^{-1}$ (Beucher et al., 2004)) have been reported previously from seawater. In addition, similar rapid decreases in the dissolution rate constants were also observed in Demarest et al. (2009), and were attributed to the decrease of overall reactive surface area and the increase of the proportion of less soluble structure as dissolution proceeded.

For DOC, a possible explanation for the differences in incorporation is its molecular composition and the affinity to the other compounds in sea ice. In contrast to the other parameters measured, DOC represents a complex mixture of compounds spanning a range in physico-chemical characteristics (e.g., hydrophobicity and size). The addition of river water in the SWR mesocosms resulted in a higher DOC concentration and higher contribution of terrestrial DOC than in the SW mesocosms. Terrestrial DOM is generally composed of older soil-derived and younger vegetation-derived material of which the former is less degradable. We therefore conclude that the addition of riverine DOC, being half of the total DOC, notably changed the composition compared to the prevailing marine (mainly phytoplankton-derived) DOC in the seawater. Thus, the SWR mesocosms contained a higher proportion of refractory DOM than SW. Our data agree with the report that the more labile forms of DOC are better retained in sea ice than the refractory forms (e.g., humic acids) (Jørgensen et al., submitted for publication; Müller et al., 2013), and that the DOC_n concentrations in ice may be even lower than in the under-ice water when the water contains higher concentrations of soil-derived DOC (Granskog et al., 2005; Hagström et al., 2001). Furthermore, Dittmar and Kattner (2003b) referred to the intramolecular contraction and coiling of humic acids with increasing salinity to explain differences of their behavior in size-exclusion chromatography. Therefore, even among different types of humic acids, there may be differences in the incorporation efficiency.

\section{Conclusion and perspectives}

The aim of our experiments was to better understand the difference in sea ice biogeochemistry from ice growth to ice decay related to additional DOC contribution and bacterial production. We reproduced the two main stages in brine dynamics that affect the biogeochemistry in natural sea ice (i.e., bottom convection and brine stratification) despite the short duration of the experiment (19 days).

The experiment has shown that dissolved compounds do not necessarily behave conservatively in relation to salinity during ice formation, consolidation and melt. Particulate organic matter incorporated into sea ice may rapidly be converted to dissolved compounds, thereby inducing a deviation from the conservative dilution curve. Such deviation from the conservative behavior is however reduced at the bottom of the ice where brine convection occurs.
Three distinct phases in bacterial abundance and carbon production were identified corresponding to physical changes. The overall cellspecific bacterial production was lower than in the starting waters, but increased one week after as a response to the bacterial growth in the ice cover. The initiation of a melting phase seemed to introduce unfavorable growth conditions for bacteria, presumably due to sudden change in brine salinity, which have induced osmotic stress on cell. Our results demonstrate that there is a direct regulation of bacterial activity by ice physical processes (brine stability and melting) and suggest that the length and periodicity of freeze-melt cycles may be important for the functioning of bacterial communities in sea ice. Although $\mathrm{NH}_{4}^{+}$ and $\mathrm{NO}_{2}^{-}$accumulations are consequences of bacterial activity, the bacterial carbon demand was too low to significantly impact the overall DOC pool in sea ice during the experiment.

This experiment has provided evidence that the inter-hemispheric difference of DOC dynamics and bacterial respiration is more complex than initially hypothesized. Indeed, although DOC concentrations are higher in the Arctic Ocean compared to those in the Southern Ocean, Arctic DOC may be less efficiently incorporated into sea ice (because of the properties of terrestrially-derived DOC). The difference in sea ice biogeochemistry between the Arctic and Southern Oceans may also depend on the amount of bio-available DOC (arising from POM in parent seawater) and the associated bacterial production, rather than the total input of allochthonous riverine DOC in seawater.

\section{Acknowledgments}

The work described in this publication was supported by the European Community's 7th Framework Programme through the grant to the budget of the Integrated Infrastructure Initiative HYDRALAB-IV, contract no. 261520. The authors would like to thank the Hamburg Ship Model Basin (HSVA), especially the ice tank crew, for their hospitality, technical and scientific support and the professional execution of the test program in the Research Infrastructure ARCTECLAB. We are grateful to C. Burau and K.-U. Ludwichowski (AWI) for nutrient and DOC measurements. We also thank the two anonymous reviewers for their thorough comments, which have improved the quality of the manuscript. JZ and BD are respectively a research fellow and a research associate of the Fonds de la Recherche Scientique-FNRS. The work was supported by a FiDiPro award by the Academy of Finland (grant no. 127097), the Walter and Andree Nottbeck Foundation, the Danish Strategic Research Council to the project NAACOS (grant no. 10-093909) and the Belgian BELSPO-BIGSOUTH grant (\# SD/CA/05A). This is a MARE contribution 279.

\section{References}

Aslam, S.N., Underwood, G.J.C., Kaartokallio, H., Norman, L., Autio, R., Fischer, M., Kuosa, H. Dieckmann, G.S., Thomas, D.N., 2012. Dissolved extracellular polymeric substances (dEPS) dynamics and bacterial growth during sea ice formation in an ice tank study. Polar Biol. 35 (5), 661-676.

Bartels, T., Eichler, B., Zimmermann, P., Gäggeler, H.W., Ammann, M., 2002. The adsorption of nitrogen oxides on crystalline ice. Atmos. Chem. Phys. 2 (3), 235-247.

Becquevort, S., Dumont, I., Tison, J.L., Lannuzel, D., Sauvee, M.L., Chou, L., Schoemann, V., 2009. Biogeochemistry and microbial community composition in sea ice and underlying seawater off East Antarctica during early spring. Polar Biol. 32 (6), 879-895.

Beucher, C., Tréguer, P., Hapette, A.-M., Corvaisier, R., Metzl, N., Pichon, J.-J., 2004. Intense summer Si-recycling in the surface Southern Ocean. Geophys. Res. Lett. 31 (9), L09305.

Bjornsen, P.K., Kuparinen, J., 1991. Determination of bacterioplankton biomass, net production and growth efficiency in the Southern Ocean. Mar. Ecol. Prog. Ser. 71, 185-194.

Carnat, G., Papakyriakou, T., Geilfus, N.-X., Brabant, F., Delille, B., Vancoppenolle, M., Gilson, G., Zhou, J., Tison, J.-L., 2013. Investigations on physical and textural properties of Arctic first-year sea ice in the Amundsen Gulf, Canada, November 2007-June 2008 (IPY-CFL system study). J. Glaciol. 59 (217), 819-837.

Codispoti, L.A., Kelly, V., Thessen, A., Matrai, P., Suttles, S., Hill, V., Steele, M., Light, B., 2013. Synthesis of primary production in the Arctic Ocean: III. Nitrate and phosphate based estimates of net community production. Prog. Oceanogr. 110, 126-150.

Cottier, F., Eicken, H., Wadhams, P., 1999. Linkages between salinity and brine channel distribution in young sea ice. J. Geophys. Res. Oceans 104 (C7), 15859-15871.

Cox, G.F.N., Weeks, W.F., 1983. Equations for determining the gas and brine volumes in sea-ice samples. J. Glaciol. 29 (102), 306-316. 
Demarest, M.S., Brzezinski, M.A., Beucher, C.P., 2009. Fractionation of silicon isotopes during biogenic silica dissolution. Geochim. Cosmochim. Acta 73 (19), 5572-5583.

Dittmar, T., Kattner, G., 2003a. The biogeochemistry of the river and shelf ecosystem of the Arctic Ocean: a review. Mar. Chem. 83 (3), 103-120.

Dittmar, T., Kattner, G., 2003b. Recalcitrant dissolved organic matter in the ocean: major contribution of small amphiphilics. Mar. Chem. 82 (1-2), 115-123.

Dittmar, T., Fitznar, H.P., Kattner, G., 2001. Origin and biogeochemical cycling of organic nitrogen in the eastern Arctic Ocean as evident from D- and L-amino acids. Geochim. Cosmochim. Acta 65 (22), 4103-4114.

Eicken, H., Grenfell, T.C., Perovich, D.K., Richter-Menge, J.A., Frey, K., 2004. Hydraulic controls of summer Arctic pack ice albedo. J. Geophys. Res. Oceans 109 (C8), C08007.

Eronen-Rasimus, E., Kaartokallio, H., Lyra, C., Autio, R., Kuosa, H., Dieckmann, G.S., Thomas, D.N., 2014. Bacterial community dynamics and activity in relation to dissolved organic matter availability during sea-ice formation in a mesocosm experiment. Microbiol. Open 3 (1), 139-156.

Fripiat, F., Corvaisier, R., Navez, J., Elskens, M., Schoemann, V., Leblanc, K., Andre, L. Cardinal, D., 2009. Measuring production-dissolution rates of marine biogenic silica by $\mathrm{Si}$-30-isotope dilution using a high-resolution sector field inductively coupled plasma mass spectrometer. Limnol. Oceanogr. Methods 7, 470-478.

Fripiat, F., Sigman, D.M., Fawcett, S.E., Rafter, P.A., Weigand, M.A., Tison, J.L., 2014. New insights into sea ice nitrogen biogeochemical dynamics from the nitrogen isotopes. Glob. Biogeochem. Cycles 28 (2), 115-130.

Fritsen, C.H., Coale, S.L., Neenan, D.R., Gibson, A.H., Garrison, D.L., 2001. Biomass, production and microhabitat characteristics near the freeboard of ice floes in the Ross Sea Antarctica, during the austral summer. Ann. Glaciol. 33 (1), 280-286.

Fritsen, C.H., Ackley, S.F., Kremer, J.N., Sullivan, C.W., 2013. Flood-freeze cycles and microalgal dynamics in Antarctic pack ice. Antarctic Sea Ice: Biological Processes, Interactions and Variability. American Geophysical Union, pp. 1-21.

Fuhrman, J.A., Azam, F., 1980. Bacterioplankton secondary production estimates for coastal waters of British Columbia, Antarctica, and California. Appl. Environ. Microbiol. 39 (6), 1085-1095.

Fuhrman, J.A., Azam, F., 1982. Thymidine incorporation as a measure of heterotrophic bacterioplankton production in marine surface waters: evaluation and field results. Mar. Biol. 66 (2), 109-120.

Gasol, J.M., Del Giorgio, P.A., 2000. Using flow cytometry for counting natural planktonic bacteria and understanding the structure of planktonic bacterial communities. Sci. Mar. 64 (2), 197-224

Gasol, J.M., Zweifel, U.L., Peters, F., Fuhrman, J.A., Hagström, Å., 1999. Significance of size and nucleic acid content heterogeneity as measured by flow cytometry in natural planktonic bacteria. Appl. Environ. Microbiol. 65 (10), 4475-4483.

Geilfus, N.-X., Carnat, G., Papakyriakou, T., Tison, J.L., Else, B., Thomas, H., Shadwick, E., Delille, B., 2012. Dynamics of $\mathrm{pCO}_{2}$ and related air-ice $\mathrm{CO}_{2}$ fluxes in the Arctic coastal zone (Amundsen Gulf, Beaufort Sea). J. Geophys. Res. Oceans 117 (C9), C00G10.

Giannelli, V., Thomas, D.N., Haas, C., Kattner, G., Kennedy, H., Dieckmann, G.S., 2001. Behaviour of dissolved organic matter and inorganic nutrients during experimental sea-ice formation. Ann. Glaciol. 33, 317-321.

Gleitz, M., Bathmann, U., Lochte, K., 1994. Build-up and decline of summer phytoplankton biomass in the eastern Weddell Sea, Antarctica. Polar Biol. 14 (6), 413-422.

Golden, K.M., Ackley, S.F., Lytle, V.I., 1998. The percolation phase transition in sea ice. Science 282 (5397), 2238-2241.

Granskog, M.A., Kaartokallio, H., Thomas, D.N., Kuosa, H., 2005. Influence of freshwater inflow on the inorganic nutrient and dissolved organic matter within coastal sea ice and underlying waters in the Gulf of Finland (Baltic Sea). Estuar. Coast. Shelf Sci. 65 (1-2), 109-122.

Grasshoff, K., Kremling, K., Ehrhardt, M., 1999. Methods of Seawater Analysis. Wiley-VCH Verlag, Weinheim, Germany.

Grossmann, S., Dieckmann, G.S., 1994. Bacterial standing stock, activity, and carbon production during formation and growth of sea ice in the Weddell Sea, Antarctica. Appl. Environ. Microbiol. 60 (8), 2746-2753.

Hagström, Å., Azam, F., Kuparinen, J., Zweifel, U.-L., 2001. Pelagic plankton growth and resource limitations in the Baltic Sea. A Systems Analysis of the Baltic Sea. Springer, pp. 177-210.

Hansell, D.A., Carlson, C.A., Repeta, D.J., Schlitzer, R., 2009. Dissolved organic matter in the ocean: a controversy stimulates new insights. Oceanography 22 (4), 202-211.

Helmke, E., Weyland, H., 1995. Bacteria in sea ice and underlying water of the eastern Weddell Sea in midwinter. Mar. Ecol. Prog. Ser. 117, 269-287.

Jørgensen, L., Stedmon, C.A., Kaartokallio, H., Middelboe, M., Thomas, D.N., 2014. Changes in the composition and bioavailability of dissolved organic matter during sea ice formation. Limnol. Oceanogr. (submitted for publication).

Kaartokallio, H., 2001. Evidence for active microbial nitrogen transformations in sea ice (Gulf of Bothnia, Baltic Sea) in midwinter. Polar Biol. 24 (1), 21-28.

Kaartokallio, H., 2004. Food web components, and physical and chemical properties of Baltic Sea ice. Mar. Ecol. Prog. Ser. 273, 49-63.

Kaartokallio, H., Søgaard, D.H., Norman, L., Rysgaard, S., Tison, J.-L., Delille, B., Thomas, D.N., 2013. Short-term variability in bacterial abundance, cell properties, and incorporation of leucine and thymidine in subarctic sea ice. Aquat. Microb. Ecol. 71 (1), 57-73.

Kattner, G., Becker, H., 1991. Nutrients and organic nitrogenous compounds in the marginal ice zone of the Fram Strait. J. Mar. Syst. 2 (3), 385-394.

Kérouel, R., Aminot, A., 1997. Fluorometric determination of ammonia in sea and estuarine waters by direct segmented flow analysis. Mar. Chem. 57 (3), 265-275.
Kirchman, D., K'nees, E., Hodson, R., 1985. Leucine incorporation and its potential as a measure of protein synthesis by bacteria in natural aquatic systems. Appl. Environ. Microbiol. 49 (3), 599-607.

Kuparinen, J., Kuosa, H., Andersson, A.J., Autio, R., Granskog, M.A., Ikävalko, J., Kaartokallio, H., Karell, K., Leskinen, E., Piiparinen, J., Rintala, J., Tuomainen, J., 2007. Role of sea-ice biota in nutrient and organic material cycles in the northern Baltic Sea. Ambio 36, 149-154.

Kuparinen, J., Autio, R., Kaartokallio, H., 2011. Sea ice bacterial growth rate, growth efficiency and preference for inorganic nitrogen sources in the Baltic Sea. Polar Biol. 34 (9), 1361-1373.

Lechtenfeld, O.J., Kattner, G., Flerus, R., McCallister, S.L., Schmitt-Kopplin, P., Koch, B.P., 2014. Molecular transformation and degradation of refractory dissolved organic matter in the Atlantic and Southern Ocean. Geochim. Cosmochim. Acta 126, 321-337.

Meese, D.A., 1989. The Chemical and Structural Properties of Sea Ice in the Southern Beaufort Sea. U.S. Army Cold Regions Research and Engineering Laboratory.

Müller, S., Vähätalo, A.V., Stedmon, C.A., Granskog, M.A., Norman, L., Aslam, S.N., Underwood, G.J.C., Dieckmann, G.S., Thomas, D.N., 2013. Selective incorporation of dissolved organic matter (DOM) during sea ice formation. Mar. Chem. 155, 148-157.

Nagata, T., Watanabe, Y., 1990. Carbon- and nitrogen-to-volume ratios of bacterioplankton grown under different nutritional conditions. Appl. Environ. Microbiol. 56 (5), 1303-1309.

Nguyen, D., Maranger, R., 2011. Respiration and bacterial carbon dynamics in Arctic sea ice. Polar Biol. 34 (12), 1843-1855.

Norman, L., Thomas, D.N., Stedmon, C.A., Granskog, M.A., Papadimitriou, S., Krapp, R.H., Meiners, K.M., Lannuzel, D., van der Merwe, P., Dieckmann, G.S., 2011. The characteristics of dissolved organic matter (DOM) and chromophoric dissolved organic matter (CDOM) in Antarctic sea ice. Deep-Sea Res. II Top. Stud. Oceanogr. 58 (9-10), 1075-1091.

Notz, D., Worster, M.G., 2008. In situ measurements of the evolution of young sea ice. J. Geophys. Res. Oceans 113 (C3), C03001.

Notz, D., Worster, M.G., 2009. Desalination processes of sea ice revisited. J. Geophys. Res. Oceans 114 (C5), C05006.

Notz, D., Wettlaufer, J.S., Worster, M.G., 2005. A non-destructive method for measuring the salinity and solid fraction of growing sea ice in situ. J. Glaciol. 51 (172), 159-166.

Pelegri, S.P., Dolan, J., Rassoulzadegan, F., 1999. Use of high temperature catalytic oxidation (HTCO) to measure carbon content of microorganisms. Aquat. Microb. Ecol. 16 (3), 273-280.

Petrich, C., Eicken, H., 2010. Growth, structure and properties of sea ice. In: Thomas, D.N., Dieckmann, G.S. (Eds.), Sea Ice. Blackwell Publishing Ltd, UK, pp. 23-77.

Pringle, D.J., Ingham, M., 2009. Thermal, electrical, and hydraulic properties of sea ice. In: Eicken, H., et al. (Eds.), Field Techniques for Sea Ice Research. University of Alaska Press, Alaska, pp. 141-180

Rysgaard, S., Glud, R.N., Sejr, M.K., Blicher, M.E., Stahl, H.J., 2008. Denitrification activity and oxygen dynamics in Arctic sea ice. Polar Biol. 31 (5), 527-537.

Smith, R.H., Clement, P., 1990. Heterotrophic activity and bacterial productivity in assemblages of microbes from sea ice in the high Arctic. Polar Biol. 10 (5), 351-357.

Stedmon, C.A., Thomas, D.N., Granskog, M., Kaartokallio, H., Papadimitriou, S., Kuosa, H., 2007. Characteristics of dissolved organic matter in Baltic coastal sea ice: allochthonous or autochthonous origins? Environ. Sci. Technol. 41 (21), 7273-7279.

Stedmon, C.A., Thomas, D.N., Papadimitriou, S., Granskog, M.A., Dieckmann, G.S., 2011. Using fluorescence to characterize dissolved organic matter in Antarctic sea ice brines. J. Geophys. Res. Biogeosci. 116 (G3), G03027.

Thomas, D.N., Lara, R.J., Eicken, H., Kattner, G., Skoog, A., 1995. Dissolved organic matter in Arctic multi-year sea ice in winter: major components and relationships to ice characteristics. Polar Biol. 15, 477-483.

Thomas, D.N., Kattner, G., Engbrodt, R., Giannelli, V., Kennedy, H., Haas, C., Dieckmann, G.S., 2001. Dissolved organic matter in Antarctic sea ice. Ann. Glaciol. 33, 297-303.

Thomas, D.N., Papadimitriou, S., Michel, C., 2010. Biogeochemistry of sea ice. In: Thomas, D.N., Dieckmann, G.S. (Eds.), Sea Ice. Blackwell Publishing Ltd, UK, pp. 425-467.

Vancoppenolle, M., Goosse, H., de Montety, A., Fichefet, T., Tremblay, B., Tison, J.L., 2010. Modeling brine and nutrient dynamics in Antarctic sea ice: the case of dissolved silica. J. Geophys. Res. Oceans 115, C02005.

Vancoppenolle, M., Notz, D., Vivier, F, Tison, J., Delille, B., Carnat, G, Zhou, J., Jardon, F, Griewank, P., Lourenço, A., Haskell, T., 2013. Technical note: on the use of the mushy-layer Rayleigh number for the interpretation of sea-ice-core data. Cryosphere Discuss. 7 (4), 3209-3230.

Weeks, W.F., 2010. On Sea Ice. University of Alaska Press, Fairbanks, Alaska (664 pp.).

Wheeler, P.A., Watkins, J.M., Hansing, R.L., 1997. Nutrients, organic carbon and organic nitrogen in the upper water column of the Arctic Ocean: implications for the sources of dissolved organic carbon. Deep-Sea Res. II Top. Stud. Oceanogr. 44 (8), 1571-1592

Worster, M.G., Wettlaufer, J.S., 1997. Natural convection, solute trapping, and channel formation during solidification of saltwater. J. Phys. Chem. B 101, 6132-6136.

Zhou, J., Delille, B., Eicken, H., Vancoppenolle, M., Brabant, F., Carnat, G., Geilfus, N.-X., Papakyriakou, T., Heinesch, B., Tison, J.-L., 2013. Physical and biogeochemical properties in landfast sea ice (Barrow, Alaska): insights on brine and gas dynamics across seasons. J. Geophys. Res. Oceans 118 (6), 3172-3189. 